\title{
Biochemical characterization of multifunctional endophytic fungi from Bambusa oldhamii Munro ${ }^{1}$
}

\author{
Andreia Alves da Costa Silveira ${ }^{2}$, Leila Garcês de Araújo3, \\ Marta Cristina Corsi de Filippi ${ }^{4}$, Fabrícia Paula de Faria ${ }^{5}$, Sérgio Tadeu Sibov ${ }^{3}$
}

\section{ABSTRACT}

In a plant-endophyte relationship, substances secreted by microorganisms can help the plant to defend itself against pathogens and also to promote an increase in biomass. This study aimed to biochemically characterize endophytic fungi from Bambusa oldhamii Munro, aiming at future studies on plant growth promotion, as well as on resistance induction. The following fungal isolates from $B$. oldhamii were used: 29 (Acrocalymma sp.); 122 (Botryobambusa fusicoccum); 711 (Phoma sp.); and 712 (Phoma sp.). Biochemical characterization was performed, analyzing the production of indole-acetic acid, chitinases and glucanases, as well as the presence or absence of polyphenol oxidases and phosphate solubilization activity in vitro. The isolate 29 produced larger amounts of indole-acetic acid and chitinases, yielding $31.55 \mathrm{mg} \mathrm{mL}^{-1}$ after $96 \mathrm{~h}$ and $2.59 \mathrm{U} \mathrm{mL}^{-1}$ after $120 \mathrm{~h}$, respectively. The isolate 122 produced an increased amount of glucanases, yielding $2.65 \mathrm{U} \mathrm{mL}^{-1}$ after $72 \mathrm{~h}$. The isolates 29, 711 and 712 produced polyphenol oxidases. The isolate 711 showed phosphate solubilization activity in vitro. These results indicate that the isolates under study show a potential for inducing resistance in plants and for future studies on the increase of plant biomass.

KEYWORDS: Antimicrobial activity, auxins, bambusicolous fungi, polyphenol oxidases.

\section{INTRODUCTION}

Endophytic fungi are increasingly targeted in sustainable agriculture, because of the compounds they can produce for the purpose of pathogens biocontrol and plant growth promotion (Suman et at. 2016). The biostimulant microorganism concept

\section{RESUMO}

Caracterização bioquímica de fungos endofíticos multifuncionais de Bambusa oldhamii Munro

Em uma relação planta-endófito, substâncias secretadas por micro-organismos podem ajudar a planta a se defender contra patógenos e promover o aumento de biomassa. Objetivou-se caracterizar bioquimicamente fungos endofíticos de Bambusa oldhamii Munro, visando a futuros estudos sobre promoção de crescimento, bem como indução de resistência. Foram utilizados os seguintes isolados fúngicos de B. oldhamii: 29 (Acrocalymma sp.); 122 (Botryobambusa fusicoccum); 711 (Phoma sp.); e 712 (Phoma sp.). Foi realizada caracterização bioquímica, analisandose a produção de ácido indolacético, quitinases e glucanases, bem como a presença ou ausência de polifenol oxidases e atividade de solubilização de fosfato in vitro. O isolado 29 produziu maiores quantidades de ácido indolacético e quitinases, rendendo

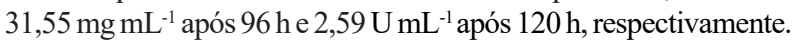
O isolado 122 produziu uma quantidade aumentada de glucanases, rendendo 2,65 $\mathrm{U} \mathrm{mL}^{-1}$ após $72 \mathrm{~h}$. Os isolados 29, 711 e 712 produziram polifenol oxidases. $\mathrm{O}$ isolado 711 apresentou atividade de solubilização de fosfato in vitro. Esses resultados indicam que os isolados em estudo apresentam potencial para indução de resistência em plantas e para futuros estudos de aumento de biomassa vegetal.

PALAVRAS-CHAVE: Atividade antimicrobiana, auxinas, fungos bambusícolas, polifenol oxidases.

includes the subcategory biofertilizer, defined as a solution containing living organisms, which, when applied to seeds, plants or soil, colonizes the plant and promotes growth by increasing the nutrient use efficiency and providing new routes of nutrient acquisition (Vessey 2003, Du Jardin 2015). These beneficial microorganisms, in turn, can induce or

${ }^{1}$ Received: Oct. 26, 2020. Accepted: Nov. 19, 2020. Published: Dec. 09, 2020. DOI: 10.1590/1983-40632020v5066370.

${ }^{2}$ Universidade Federal de Goiás, Escola de Agronomia, Goiânia, GO, Brasil. E-mail/ORCID: andreiaac2@gmail.com/0000-0001-8562-846X.

${ }^{3}$ Universidade Federal de Goiás, Instituto de Ciências Biológicas, Departamento de Biologia Geral, Goiânia, GO, Brasil. E-mail/ORCID: leilagarcesaraujo@gmail.com/0000-0002-3238-4999, stsibov@gmail.com/0000-0001-6404-8271.

${ }^{4}$ Empresa Brasileira de Pesquisa Agropecuária (Embrapa Arroz e Feijão), Laboratório de Fitopatologia, Santo Antônio de Goiás, GO, Brasil.E-mail/ORCID: cristina.filippi@embrapa.br/0000-0002-6575-9179.

${ }^{5}$ Universidade Federal de Goiás, Instituto de Ciências Biológicas, Departamento de Bioquímica e Biologia Molecular, Goiânia, GO, Brasil.E-mail/ORCID: fabriciapfaria@hotmail.com/0000-0002-8534-8131. 
produce auxins that improve the plant growth $(\mathrm{Du}$ Jardin 2015) and produce enzymes that help the plant to defend itself from pathogens (Nascimento et al. 2018). The enzymes secreted by endophytes include: chitinases, glucanases (which degrade the cell wall of pathogens) and polyphenol oxidases (responsible for the natural defense process of plants) (Mishra \& Gautam 2016). Biofertilizer microorganisms are also defined as organic matter decomposers (cellulolytic), auxin producers and potassium and phosphate solubilizers (Board 2004, Rai 2006, Boraste et al. 2009, Meena et al. 2016). This last group has attracted the interest of farmers for several reasons, including the finite nature of phosphate deposits (Scholz et al. 2013); the fact that phosphate has an anionic form, becoming insoluble and unavailable to plants when coming into contact with other minerals in the soil (Lopez-Bucio et al. 2003); and the high cost of chemical fertilization (Zaidi et al. 2009).

Bambusicolous fungi (formerly fungorum bambusicolorum) are estimated to include more than 1,450 species in approximately 115 genera around the world (Dai et al. 2017). These fungi, which are associated with bamboo species, are important because of the biochemical compounds they produce, such as antimicrobial compounds (Du et al. 2015). We previously identified 4 out of 5 promising bamboo endophytes with antibiosis activities, characterized by direct and indirect antagonism against Pyricularia oryzae (ranging from 70 to $95 \%$ less mycelial growth of pathogen colonies). The described isolates were: 29 (Acrocalymma sp.); 122 (Botryobambusa fusicoccum); 711 (Phoma sp.); and 712 (Phoma sp.) (Silveira 2020). Thus, it is necessary to identify potential enzymes in these isolates, in order to conduct future studies on resistance induction in plants.

With the impending crisis of diminishing phosphate deposits and the unrestrained use of chemical fertilizers and pesticides, biostimulant microorganisms have become important for agriculture (Adesemoye \& Kloepper 2009, Zaidi et al. 2009). This is because, in addition to nourishing plants, they can promote growth and produce and secrete enzymes that confer resistance to pathogens (Whitelaw 1999, Naznin et al. 2014). However, before conducting field tests using these microorganisms, the enzymes must first be identified and the potential fungi selected.

Given that, a biostimulant microorganism may also be a source of pathogen-inhibiting substances (Du Jardin 2015), and the fungal isolates identified by Silveira et al. (2020) are candidates for studies involving the biochemical characterization of these microorganisms, aimed at identifying chemical substances related to both the biostimulant action and resistance induction in plants. Thus, this study was carried out to identify and biochemically characterize endophytic fungi from Bambusa oldhamii Munro, aiming at future plant growth promoting protocols with these fungal isolates.

\section{MATERIAL AND METHODS}

Four endophytes isolated from B. oldhamii were used in the present study: 29 (Acrocalymma sp.; GenBank accession number MN381026); 122 (Botryobambusa fusicoccum; MN381103); 711 (Phoma sp.; MN381110); and 712 (Phoma sp.; MN383185). These fungi were selected due to their promising antagonistic activity against Pyricularia oryzae, previously described by Silveira et al. (2020). The experiments were carried out between March and May 2016.

For quantitation of chitinases and glucanases, five 5-mm mycelial discs of each fungal isolate were grown in $100 \mathrm{~mL}$ of modified minimal medium $\left(0.6 \%\right.$ of $\mathrm{NaNO}_{3}, 0.05 \%$ of $\mathrm{KCl}, 0.15 \%$ of $\mathrm{KH}_{2} \mathrm{PO}_{4}$, $0.001 \%$ of $\mathrm{FeSO}_{4}, 0.25 \%$ of yeast extract, $0.25 \%$ of $\left(\mathrm{NH}_{4}\right)_{2} \mathrm{SO}_{4} ; 0.001 \%$ of $\mathrm{ZnSO}_{4}$ ) (Pontecorvo et al. 1953) supplemented with two different carbon sources: $0.5 \%$ colloidal chitin and $2 \%$ glucose $(\mathrm{w} / \mathrm{v})$. The cultures were kept in Erlenmeyer flasks at $120 \mathrm{rpm}$ and $28{ }^{\circ} \mathrm{C}$, for $144 \mathrm{~h}$. Every 24 hours, 1-mL samples were taken from each Erlenmeyer flask, transferred to microtubes, centrifuged at $5,000 \mathrm{rpm}$ for $15 \mathrm{~min}$ and used as a source of enzymes (Noronha \& Ulhoa 2000, Almeida et al. 2007).

The chitinase activity was determined using $50 \mu \mathrm{L}$ aliquots from each sample, in triplicate, with $300 \mu \mathrm{L}$ of $1 \%$ chitin in $1.0 \mathrm{M}$ sodium acetate buffer, $\mathrm{pH}$ 5.0. After incubation at $37^{\circ} \mathrm{C}$ for $120 \mathrm{~min}$, the reaction product was quantified using the DNS (3,5-dinitrosalicylic acid) colorimetric method (Miller 1959). To that end, $1 \mathrm{~mL}$ of DNS was added to each sample, and the reaction incubated at $100{ }^{\circ} \mathrm{C}$, for $5 \mathrm{~min}$. The amount of reducing sugars was determined in a spectrophotometer at $540 \mathrm{~nm}$. One unit of enzyme activity (U) was defined as the amount of enzyme required to release $1 \mu \mathrm{mol}$ of reducing sugar per minute. 
The activity of $\beta$-1,3-glucanases was determined using $50 \mu \mathrm{L}$ extracts from each sample, in triplicate, by adding $300 \mu \mathrm{L}$ of $0.75 \%$ laminarin to $1.0 \mathrm{M}$ sodium acetate buffer, $\mathrm{pH}$ 5.0. After incubation at $37^{\circ} \mathrm{C}$, for $30 \mathrm{~min}$, the quantification of the reaction product followed the same colorimetric method used for the chitinase activity.

For the auxin quantification, five mycelial discs of each fungal isolate were placed in Erlenmeyer flasks (150 mL capacity) containing $50 \mathrm{~mL}$ of $\mathrm{PD}$ medium [potato $\left(200 \mathrm{~g} \mathrm{~L}^{-1}\right)$ and dextrose $\left(20 \mathrm{~g} \mathrm{~L}^{-1}\right)$ ], supplemented with L-tryptophan $\left(100 \mathrm{mg} \mathrm{L}^{-1}\right)$ or in the absence of L-tryptophan (control). The experiment was carried out in triplicate. Every 2 days, during the 8 days of growth, in a rotary shaker at $150 \mathrm{rpm}$ and $26 \pm 2{ }^{\circ} \mathrm{C}$, a $1 \mathrm{~mL}$ aliquot of culture medium containing the fungal isolates was removed. The mycelium was separated by centrifugation at $12,000 \mathrm{rpm}$, for $15 \mathrm{~min}$. For the colorimetric analysis of indole acetic acid (IAA), $100 \mu \mathrm{L}$ of Salkowski's reagent $\left[\mathrm{FeCl}_{3} 0.5 \mathrm{~mol} \mathrm{~L}-1+\mathrm{HClO}_{4}\right.$ (35\%)] and $150 \mu \mathrm{L}$ of the supernatant were used. After a qualitative verification of the IAA presence (pink color after $25 \mathrm{~min}$, at $28{ }^{\circ} \mathrm{C}$, in the dark), the hormone was quantified in a spectrophotometer at $540 \mathrm{~nm}$. Concentrations in $\mu \mathrm{g} \mathrm{mL}^{-1}$ were calculated from a standard curve with known concentrations of the synthetic form of the hormone $\left(0-100 \mu \mathrm{g} \mathrm{mL}^{-1}\right)$ and used to calculate the IAA concentration in the samples (Oliveira et al. 2012).

The design was completely randomized, with 4 treatments (4 fungal isolates) and 3 replications. The data were submitted to analysis of variance and the means compared by the Tukey test at $5 \%$ of significance. The R software, version 3.4.3 (R Core Team 2017), was used to analyze the data and the GraphPad Prism (Radushev 2007) for graphing.

For phosphate solubilization, a 5-mm mycelial disc of each isolate was placed in Petri dishes containing $30 \mathrm{~mL}$ of TSA medium [Trypticase Soy Agar $(1 / 10-\mathrm{w} / \mathrm{v})]$ to which $\mathrm{CaHPO}_{4}$ was added and the $\mathrm{pH}$ adjusted to 7.0. The experiment was carried out in triplicate. The dishes were incubated at $28-30{ }^{\circ} \mathrm{C}$ until the control achieved full growth (dishes containing each isolate without addition of the phosphorus source). The solubilization potential was determined by the formation of a clear halo around the colony in the culture medium (Cattelan 1999).

The qualitative production of polyphenol oxidase was determined according to the
Bavendamm's reaction (Conceição et al. 2005). A $50-\mathrm{mm}$ mycelial disc of each isolate was placed in Petri dishes containing $30 \mathrm{~mL}$ of AAYE medium [agar $\left(20 \mathrm{~g} \mathrm{~L}^{-1}\right)$; tannic acid $\left(5 \mathrm{~g} \mathrm{~L}^{-1}\right)$; yeast extract $\left(15 \mathrm{~g} \mathrm{~L}^{-1}\right)$; and sucrose $\left.\left(5 \mathrm{~g} \mathrm{~L}^{-1}\right)\right]$. The dishes were incubated at $28-29^{\circ} \mathrm{C}$, with a photoperiod of $12 \mathrm{~h}$ of light, for five days. The experiment was performed in triplicate. The formation of an amber halo around the colony in the culture medium indicated a qualitative production of polyphenol oxidases (Cattelan 1999).

\section{RESULTS AND DISCUSSION}

All isolates produced chitinases and glucanases on both substrates (chitin and glucose) (Figures 1 and 2, respectively). The isolate 29 (Acrocalymma sp.) was notable, with the highest production of chitinases $\left(2.59 \mathrm{U} \mathrm{mL}^{-1}\right)$ after $120 \mathrm{~h}$ of incubation (using chitin as substrate) (Figure 1). The isolate 711 (Phoma sp.) produced the highest number of chitinases using glucose as substrate, exhibiting $2.61 \mathrm{U} \mathrm{mL}^{-1}$ at $48 \mathrm{~h}$, with a $53.93 \%$ increase, if compared to the other isolates (Figure 1). However, this isolate was not distinctive when cultured in medium supplemented with chitin (Figure 2).

The isolates 122 (Botryobambusa fusicoccum), 29 and 711 may be the target of future studies regarding induced resistance against pathogens, because a significant glucanase or chitinase production was observed. This corroborates the results previously determined in in vitro antagonism against $P$. oryzae, whereby a high inhibition of the pathogen was observed when these isolates were used, mainly the isolate 122 (Silveira et al. 2020).

The isolate 122 secreted $\beta$-1,3-glucanases in the presence of chitin and glucose (Figure 2), and, at 24, 120 and $144 \mathrm{~h}$, the culture medium supplemented with glucose obtained high averages of these enzymes, whereas, at $72 \mathrm{~h}$, the culture medium supplemented with chitin exhibited an average production for this isolate.

Differences were observed in relation to the best enzyme production time for each isolate. For example, the isolate 29 had its highest chitinase production after $120 \mathrm{~h}$ of incubation. On the other hand, the isolate 711 produced a higher number of these enzymes between 48 and $73 \mathrm{~h}$. These differences for high chitinase production at different incubation times can be useful in the specificity of plant response to different pathogens. An example of this occurs in 


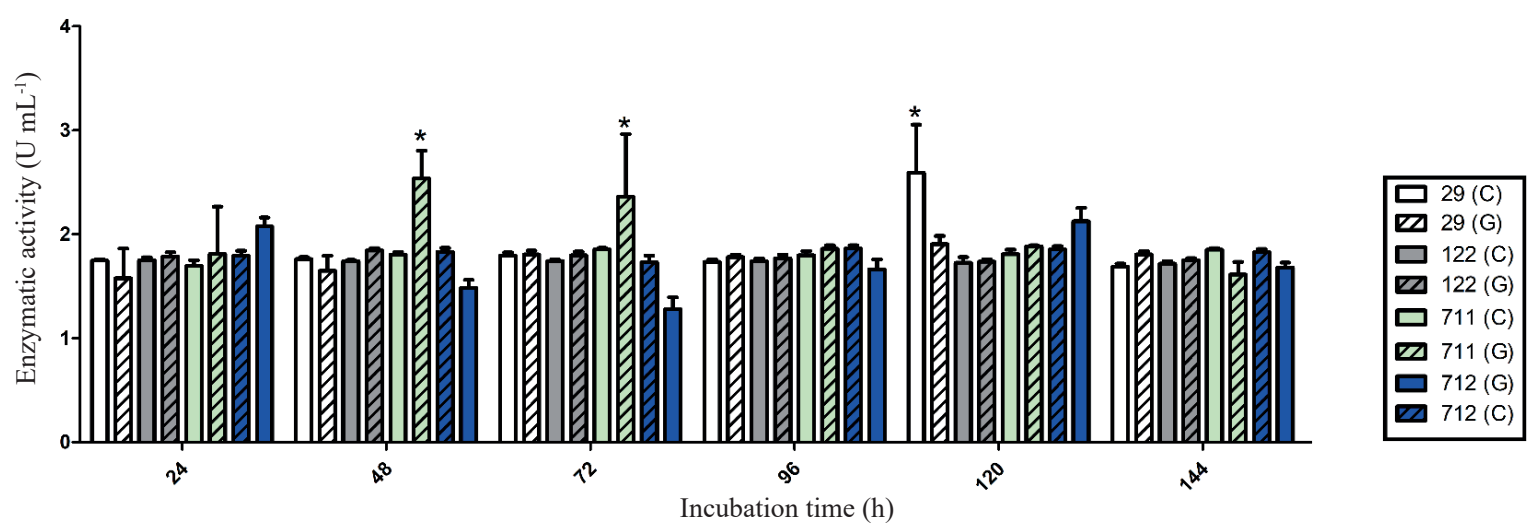

Figure 1. Means and standard errors of the time variation in the chitinolytic activity of endophytic fungi from Bambusa oldhamii [isolates 29 (Acrocalymma sp.), 122 (Botryobambusa fusicoccum), 711 (Phoma sp.) and 712 (Phoma sp.)], using $0.5 \%$ chitin $(\mathrm{C})$ or $0.2 \%$ glucose $(\mathrm{G})$ as substrate. Means followed by an asterisk $\left(^{*}\right)$ are significantly different (within the incubation time), according to the Tukey test $(\alpha=0.05)$.



Figure 2. Time variation in the activity of $\beta$-1,3-glucanases of endophytic fungi from Bambusa oldhamii [isolates 29 (Acrocalymma sp.), 122 (Botryobambusa fusicoccum), 711 (Phoma sp.) and 712 (Phoma sp.)], using $0.5 \%$ chitin (C) or $0.2 \%$ glucose $(\mathrm{G})$ as substrate. Means followed by an asterisk $(*)$ are significantly different (within the incubation time), according to the Tukey test $(\alpha=0.05)$.

wheat infection by Pyricularia oryzae, with a high disease severity observed after $120 \mathrm{~h}$ (Aucique-Pérez et al. 2020). On the other hand, the Rhizoctonia solani infection in potato increases from 8 to $12 \mathrm{~h}$ after the inoculation, what requires a faster defense response time (Zhang et al. 2016). Thus, further greenhouse studies are needed to confirm this potential.

The choice of carbon source for lytic enzyme production is important, because it is influenced by the culture medium components. In general, the excess of glucose or other readily available carbons may suppress the production of glucanases, such as in Penicillium italicum (Santos et al. 1978, Bielecki \& Galas 1991). However, the isolate 122 (Botryobambusa fusicoccum) secreted $\beta$-1,3-glucanase in the presence of chitin and glucose (Figure 2), releasing greater amounts of this carbohydrate than in the culture medium. Other microorganisms have been reported as glucanase producers in the presence of glucose as a carbon source, such as Trichoderma viride, Saccharomyces cerevisiae (Del Rey et al. 1979) and Candida albicans (Molina et al. 1989), which do not undergo catabolic repression of $\beta-1,3$ and $\beta$-1,6-glucanases during the growth phase. Chitinases and glucanases are involved in the degradation of pathogen cell walls, what can reduce the severity of diseases (Agrios 2005, Langner \& Göhre 2016, Ribeiro et al. 2019). Thus, further greenhouse studies are needed to investigate this potential.

All the isolates produced IAA in the first incubation period evaluated at $48 \mathrm{~h}$ (Table 1). During this incubation time, the isolate 711 produced a large 
Table 1. In vitro biochemical characterization of Bambusa oldhamii isolates evaluated qualitatively.

\begin{tabular}{lccc}
\hline \multicolumn{1}{c}{ Isolate } & Indole acetic acid & Phosphate solubilization & Polyphenol oxidases \\
\hline 29 (Acrocalymma sp.) & + & - & + \\
122 (Botryobambusa fusicoccum $)$ & + & - & - \\
711 (Phoma sp.) & + & + & + \\
712 (Phoma sp.) & + & - & + \\
\hline
\end{tabular}

+ positive production; - no production.

amount of IAA (average of $9.67 \mathrm{mg} \mathrm{mL}^{-1}$ ), a $544.67 \%$ increase over the isolate 122, in the same time period (Figure 3). However, after $96 \mathrm{~h}$, the isolate 29 had the highest IAA production, with $5.16 \mathrm{mg} \mathrm{mL}^{-1}$ at $48 \mathrm{~h}$, increasing to $17.11 \mathrm{mg} \mathrm{mL}^{-1}$ at $96 \mathrm{~h}$. At $192 \mathrm{~h}$, this isolate reached $31.66 \mathrm{mg} \mathrm{mL}^{-1}$, an increase of $2,752.25 \%$, in relation to the isolate 122 (Botryobambusa fusicoccum), in the same incubation time.

The isolate 29 exhibited a higher IAA production and shows potential for use in future biofertilization experiments. The differential factor of microorganisms that have the ability to synthesize IAA is related to growth promotion and auxin regulation in plants (Duca et al. 2014). Hu et al. (2018) studied the in vitro production of IAA by Phomopsis liquidmbari and found that the increase in rice biomass was due to inoculation by these strains. Thus, new experiments should be carried out to confirm the potential for biomass production when the fungal isolates 29 and 711 are inoculated into plants.

The isolate 711 was able to solubilize phosphate in vitro, as evidenced by the formation of a clear halo

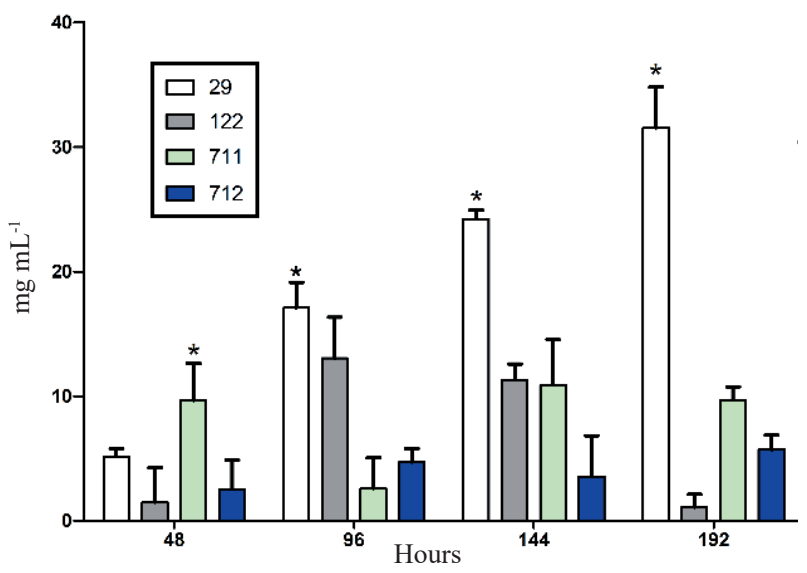

Figure 3. Production of indole acetic acid by isolates from Bambusa oldhamii [29 (Acrocalymma sp.); 122 (Botryobambusa fusicoccum); 711 (Phoma sp.); 712 (Phoma sp.)]. * Significantly different (within the incubation time), according to the Tukey test $(\alpha=0.05)$. around the colony in the culture medium (Figure 4c). The isolates 29, 711 and 712 (Phoma sp.) produced polyphenol oxidases (Table 1), exhibiting an amber halo in the AAYE medium, indicating the production of polyphenol oxidases (Figures $4 \mathrm{a}$ and $4 \mathrm{~b}$ ).

In general, phosphate solubilizing fungi include Aspergillus, Penicillium (Whitelaw 1999, Elias et al. 2016) and Trichoderma (Chagas et al. 2015, França et al. 2017), as well as mycorrhizal fungi (Richardson 2001). Although Phoma is a group that includes phytopathogenic species (Vishniac 1996), many other species are reported as growth promoters (Chandanie et al. 2005, Naznin et al. 2013) and resistance inducers in plants (Hossain et al. 2008), such as $P$. herbarum, which is reported as a gibberellin producer $\left(\mathrm{GA}_{4}\right.$ and $\left.\mathrm{GA}_{7}\right)$ and can increase the biomass in soybean and rice (Hamayun et al. 2009). A study with Arabidopsis thaliana indicated that an increase in fasciculated roots resulted from the application of moderate amounts of phosphate, which must be balanced with auxins, because increases in the former inhibit the latter (Williamson 2001, Lopez-Bucio 2002).

Phosphate solubilizing microorganisms have been described in bamboo species. In a study with Bambusa bambos endophytes (Ruangsanka 2014), the authors reported an increased biomass in Zea mays plants inoculated with bamboo endophytes, what was also confirmed in in vitro phosphate solubilization assays. The endophyte study of Phyllostachys edulis carried out by Yuan et al. (2015) also points out the potential of phosphate solubilization by bambusicolous fungi, with positive results. Thus, further studies should be carried out both for the quantification of phosphates and with field tests using this isolate.

Polyphenol oxidases are linked to the inhibition of pathogenic activities and activation of plant resistance mechanisms. Although both plants and fungi can produce polyphenol oxidases, those produced by endophytes also play a role in defending 



Figure 4. Bavendamm reaction for the qualitative evaluation of polyphenol oxidase production by the presence of an amber halo around the colony in the AAYE culture medium: a) 29 (Acrocalymma sp.); b) 712 (Phoma sp.); c) phosphate solubilization in vitro by the isolate 711 (Phoma sp.), indicated by the formation of a transparent halo around the colony in the culture media. Petri dish $=90 \times 90 \mathrm{~mm}$.

the plants against pathogens (Mayer 2006). Other study also found that polyphenol oxidases induce herbivore defense in tomato and other plants due to the jasmonate effect (Constabel \& Barbehenn 2008). Thus, further greenhouse experiments using the isolates of this study are needed to confirm this relationship.

\section{CONCLUSIONS}

1. The isolates 711 (Phoma sp.) and 29 (Acrocalymma sp.) exhibited basic characteristics as potential plant growth promoters, given their capacity of phosphate solubilization (in the case of the isolate 711) and indole acetic acid production (both isolates);

2. The isolates 29, 711 and 122 (Botryobambusa fusicoccum) may be a source of future in vivo studies, regarding induced resistance against pathogens, because significant productions of glucanases or chitinases were observed. The chitinase production was increased by the isolates 711 (when glucose was used as substrate) and 29 (in the presence of chitin), with a high glucanase production also observed for the isolate 122 , both in glucose and chitin.

\section{REFERENCES}

ADESEMOYE, A. O.; KLOEPPER, J. W. Plant-microbes interactions in enhanced fertilizer-use efficiency. Applied Microbiology and Biotechnology, v. 85, n. 1, p. 1-12, 2009.

AGRIOS, G. N. Plant pathology. 5. ed. Burlington: Elsevier, 2005.
ALMEIDA, F. B. D. R.; CERQUEIRA, F. M.; SILVA, R. N.; ULHOA, C. J.; LIMA, A. L. Mycoparasitism studies of Trichoderma harzianum strains against Rhizoctonia solani: evaluation of coiling and hydrolytic enzyme production. Biotechnology Letters, v. 29, n. 8, p. 11891193, 2007.

AUCIQUE-PÉREZ, C. E.; RESENDE, R. S.; MARTINS, A. O.; SILVEIRA, P. R.; CAVALCANTI, J. H. F.; VIEIRA, N. M.; FERNIE, A. R.; ARAÚJO, W. L.; DAMATTA, F. M.; RODRIGUES, F. A. How do wheat plants cope with Pyricularia oryzae infection?: a physiological and metabolic approach. Planta, v. 252, n. 2, e24, 2020.

BIELECKI, S.; GALAS, E. Microbial beta-glucanases different from cellulases. Critical Reviews in Biotechnology, v. 10, n. 4, p. 275-304, 1991.

BOARD, N. The complete technology book on biofertilizers and organic farming. Kamla Nagar: National Institute of Industrial Research, 2004.

BORASTE, A.; VAMSI, K. K.; JHADAV, A.; KHAIRNAR, Y.; GUPTA, N.; TRIVED, I. S.; PATIL, P.; GUPTA, G.; GUPTA, M.; MUJAPARA, A. K.; JOSHI, B. Biofertilizers: a novel tool for agriculture. International Journal of Microbiology Research, v. 1, n. 2, p. 975-5276, 2009.

CATTELAN, A. J. Métodos qualitativos para determinação de características bioquímicas e fisiológicas associadas com bactérias promotoras do crescimento vegetal. Londrina: Embrapa Soja, 1999.

CHAGAS, L. F. B.; CHAGAS JUNIOR, A. F.; CARVALHO, M. R.; MILLER, L. O.; COLONIA, B. S. O. Evaluation of the phosphate solubilization potential of Trichoderma strains (Trichoplus JCO) and effects on rice biomass. Journal of Soil Science and Plant Nutrition, v. 15, n. 3, p. 794-804, 2015. 
CHANDANIE, W. A.; KUBOTA, M.; HYAKUMACHI, $M$. Interaction between arbuscular mycorrhizal fungus Glomus mosseae and plant growth promoting fungus Phoma sp. on their root colonization and growth promotion of cucumber (Cucumis sativus L.). Mycoscience, v. 46, n. 3, p. 201-204, 2005.

CONCEIÇÃO, D. M.; ANGELIS, D. A.; BIDOIA, E. D.; ANGELIS, D. F. Fungos filamentosos isolados do Rio Atibaia, SP, e refinaria de petróleo biodegradadores de compostos fenólicos. Arquivos do Instituto Biológico, v. 72, n. 1, p. 99-106, 2005.

CONSTABEL, C. P.; BARBEHENN, R. Defensive roles of polyphenol oxidase in plants. In: SCHALLER, A. Induced plant resistance to herbivory. Dordrecht: Springer, 2008. p. 253-270.

DAI, D. Q.; PHOOKAMSAK, R.; WIJAYAWARDENE, N. N.; LI, W. J.; BHAT, D. J.; XU, J. C.; TAYLOR, J. E.; HYDE, K. D.; CHUKEATIROTE, E. Bambusicolous fungi. Fungal Diversity, v. 82, n. 1, p. 1-105, 2017.

DEL REY, F.; GARCIA-ACHA, I.; NOMBELA, C. The regulation of $\beta$-glucanase synthesis in fungi and yeast. Microbiology, v. 110, n. 1, p. 83-89, 1979.

DU JARDIN, P. Plant biostimulants: definition, concept, main categories and regulation. Scientia Horticulturae, v. 196, n. 1, p. 3-14, 2015.

DU, W.; LIANG, J.; HAN, Y.; YU, J.; LIANG, Z. Nitric oxide mediates hypocrellin accumulation induced by fungal elicitor in submerged cultures of Shiraia bambusicola. Biotechnology Letters, v. 37, n. 1, p. 153159, 2015.

DUCA, D.; LORV, J.; PATTEN, C.; ROSE, D.; GLICK, B. Indole-3-acetic acid in plant-microbe interactions. Antonie van Leeuwenhoek Journal of Microbiology, v. 106, n. 1, p. 85-125, 2014.

ELIAS, F.; WOYESSA, D.; MULETA, D. Phosphate solubilization potential of rhizosphere fungi isolated from plants in Jimma zone, southwest Ethiopia. International Journal of Microbiology, v. 2016, e5472601, 2016.

FRANÇA, D. V. C.; KUPPER, K. C.; MAGRI, M. M. R.; GOMES, T. M.; ROSSI, F. Trichoderma spp. isolates with potential of phosphate solubilization and growth promotion in cherry tomato. Pesquisa Agropecuária Tropical, v. 47, n. 4, p. 360-368, 2017.

HAMAYUN, M.; KHAN, S. A.; KHAN, A. L.; REHMAN, G.; SOHN, E. Y.; SHAH, A. A.; KIM, S. K.; JOO, G. J.; LEE, I. J. Phoma herbarum as a new gibberellinproducing and plant growth-promoting fungus. Journal of Microbiology and Biotechnology, v. 19, n. 10, p. 12441249, 2009.

HOSSAIN, M. M.; SULTANA, F.; KUBOTA, M.; KOYAMA, H.; HYAKUMACHI, M. Systemic resistance to bacterial leaf speck pathogen in Arabidopsis thaliana induced by the culture filtrate of a plant growth-promoting fungus (PGPF) Phoma sp. GS8-1. Journal of General Plant Pathology, v. 74, n. 3, p. 213-221, 2008.

HU, L.; LI, D.; SUN, K.; CAO, W.; FU, W. Q.; ZHANG, W.; DAI, C. C. Mutualistic fungus Phomopsis liquidambari increases root aerenchyma formation through auxin-mediated ethylene accumulation in rice (Oryza sativa L.). Plant Physiology and Biochemistry, v. 130, n. 1, p. 367-376, 2018.

LANGNER, T.; GÖHRE, V. Fungal chitinases: function, regulation, and potential roles in plant/pathogen interactions. Current Genetics, v. 62, n. 2, p. 243-254, 2016.

LOPEZ-BUCIO, J. Phosphate availability alters architecture and causes changes in hormone sensitivity in the arabidopsis root system. Plant Physiology, v. 129, n. 1, p. 244-256, 2002.

LOPEZ-BUCIO, J.; CRUZ-RAMIREZ, A.; HERRERAESTRELLA, L. The role of nutrient availability in regulating root architecture. Current Opinion in Plant Biology, v. 6, n. 3, p. 280-287, 2003.

MAYER, A. M. Polyphenol oxidases in plants and fungi: going places?: a review. Phytochemistry, v. 67, n. 21, p. 2318-2331, 2006.

MEENA, V. S.; MAURYA, B. R.; VERMA, J. P.; MEENA, R. S. Potassium solubilizing microorganisms for sustainable agriculture. Varanasi: Springer, 2016.

MILLER, G. L. Use of dinitrosalicylic acid reagent for determination of reducing sugar. Analytical Chemistry, v. 31, n. 3, p. 426-428, 1959.

MISHRA, B. B.; GAUTAM, S. Polyphonel oxidases: biochemical and molecular characterization, distribution, role and its control. Enzyme Engineering, v. 5, n. 1, p. 141149, 2016.

MOLINA, M.; CENAMOR, R.; SANCHEZ, M.; NOMBELA, C. Purification and some properties of Candida albicans exo-1,3-beta-glucanase. Journal of General Microbiology, v. 135, n. 2, p. 309-314, 1989.

NASCIMENTO, I. O.; RODRIGUES, A. A. C.; BRAUN, H.; SANTOS, C. C.; CATARINO, A. M. Silicon fertilization and seed microbiolization on disease severity and agronomic performance of upland rice. Revista Caatinga, v. 31, n. 1, p. 126-134, 2018.

NAZNIN, H.; KIYOHARA, D.; KIMURA, M.; MIYAZAWA, M.; SHIMIZU, M.; HYAKUMACHI, M. Systemic resistance induced by volatile organic compounds emitted by plant growth-promoting fungi in Arabidopsis thaliana. PLoS One, v. 9, n. 1, e86882, 2014. 
NAZNIN, H. A.; KIMURA, M.; MIYAZAWA, M.; HYAKUMACHI, M. Analysis of volatile organic compounds emitted by plant growth-promoting fungus Phoma sp. GS8-3 for growth promotion effects on tobacco. Microbes and Environments, v. 28, n. 1, p. 42-49, 2013.

NORONHA, E. F.; ULHOA, C. J. Characterization of a 29-kDa beta-1,3-glucanase from Trichoderma harzianum. FEMS Microbiology Letters, v. 183, n. 1, p. 119-123, 2000.

OLIVEIRA, A. G. de; CHAGAS JUNIOR, A. F.; SANTOS, G. R.; MILLER, L. O.; CHAGAS, L. F. B. Potential phosphate solubilization and AIA production of Trichoderma spp. Revista Verde de Agroecologia e Desenvolvimento Sustentável, v. 7, n. 3, p. 149-155, 2012.

PONTECORVO, G.; ROPER, J. A.; CHEMMONS, L. M.; MACDONALD, K. D.; BUFTON, A. W. J. The genetics of Aspergillus nidulans. In: DEMEREC, M. (ed.). Advances in Genetics. Glascow: Academic Press, 1953. p. 141-238.

R CORE TEAM. $R$ : a language and environment for statistical computing. Vienna: R Foundation for Statistical Computing, 2017.

RADUSHEV, D. GraphPad Prism. San Diego: GraphPad Software Inc., 2007.

RAI, M. K. Handbook of microbial biofertilizers. New York: Food Products Press, 2006.

RIBEIRO, M. S.; PAULA, R. G.; VOLTAN, A. R.; CASTRO, R. G.; CARRARO, C. B.; ASSIS, L. J.; STEINDORFF, A. S.; GOLDMAN, G. H.; SILVA, R. N.; ULHOA, C. J.; NEVES MONTEIRO, V. Endo- $\beta-1,3-$ glucanase (GH16 family) from Trichoderma harzianum participates in cell wall biogenesis but is not essential for antagonism against plant pathogens. Biomolecules, v. 9, n. 12, p. 1-17, 2019.

RICHARDSON, A. E. Prospects for using soil microorganisms to improve the acquisition of phosphorus by plants. Australian Journal of Plant Physiology, v. 28, n. 9, p. 897-906, 2001.

RUANGSANKA, S. Identification of phosphatesolubilizing bacteria from the bamboo rhizosphere. Science Asia, v. 40, n. 1, p. 204-211, 2014.

SANTOS, T.; SANCHEZ, M.; VILLANUEVA, J. R.; NOMBELA, C. Regulation of the beta-1,3-glucanase system in Penicillium italicum: glucose repression of the various enzymes. Journal of Bacteriology, v. 133, n. 2, p. 465-471, 1978.

SCHOLZ, R. W.; ULRICH, A. E.; EILITTÄ, M.; ROY, A. Sustainable use of phosphorus: a finite resource. Science of the Total Environment, v. 461-462, n. 1, p. 799-803, 2013.

SILVEIRA, A. A. C.; ARAÚJO, L. G.; FILLIPI, M. C. C; SIBOV, S. T. Isolation, identification and characterization of endophytic fungi of Bambusa oldhamii Munro applied as antagonists to Pyricularia oryzae. Revista Ceres, v. 67, n. 4, p. 296-305, 2020.

SUMAN, A.; NATH YADAV, A.; VERMA, P. Endophytic microbes in crops: diversity and beneficial impact for sustainable agriculture. In: SINGH D.; SINGH H.; PRABHA, R. Microbial inoculants in sustainable agricultural productivity: research perspectives. New Delhi: Springer, 2016. p. 117-143.

VESSEY, J. K. Plant growth promoting rhizobacteria as biofertilizers. Plant and Soil, v. 255, n. 2, p. 571-586, 2003.

VISHNIAC, H. S. Biodiversity of yeasts and filamentous microfungi in terrestrial Antarctic ecosystems. Biodiversity and Conservation, v. 5, n. 11, p. 1365-1378, 1996.

WHITELAW, M. A. Growth promotion of plants inoculated with phosphate-solubilizing fungi. In: SPARKS, D. L. (ed.). Advances in Agronomy. Wagga Wagga: Academic Press, 1999. p. 99-151.

WILLIAMSON, L. C. Phosphate availability regulates root system architecture in arabidopsis. Plant Physiology, v. 126, n. 2, p. 875-882, 2001.

YUAN, Z. S.; LIU, F.; ZHANG, G. F. Characteristics and biodiversity of endophytic phosphorus- and potassium solubilizing bacteria in moso bamboo (Phyllostachys edulis). Acta Biologica Hungarica, v. 66, n. 4, p. 449459, 2015.

ZAIDI, A.; KHAN, M. S.; AHEMAD, M.; OVES, M. Plant growth promotion by phosphate solubilizing bacteria. Acta Microbiologica et Immunologica Hungarica, v. 56, n. 3, p. 263-284, 2009.

ZHANG, X. Y. ; HUO, H. L.; XI, X. M.; LIU, L. L.; YU, Z.; HAO, J. J. Histological observation of potato in response to Rhizoctonia solani infection. European Journal of Plant Pathology, v. 145, n. 2, p. 289-303, 2016. 